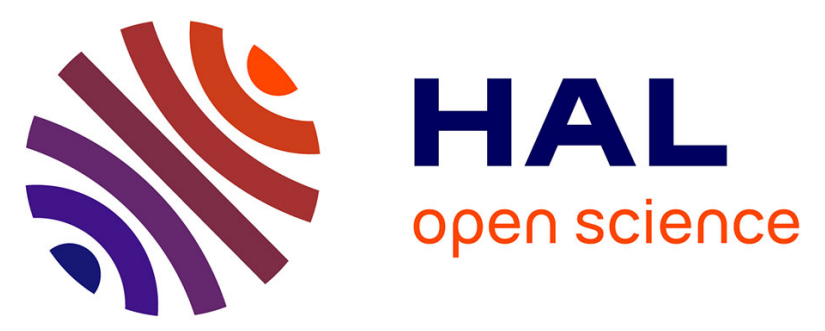

\title{
Increased levels and defective glycosylation of MRPs in ovarian carcinoma cells resistant to oxaliplatin
}

\author{
Giovanni Luca Beretta, Valentina Benedetti, Giacomo Cossa, Yehuda G.A. \\ Assaraf, Eran Bram, Laura Gatti, Elisabetta Corna, Nives Carenini, Donato \\ Colangelo, Stephen B. Howell, et al.
}

\section{To cite this version:}

Giovanni Luca Beretta, Valentina Benedetti, Giacomo Cossa, Yehuda G.A. Assaraf, Eran Bram, et al.. Increased levels and defective glycosylation of MRPs in ovarian carcinoma cells resistant to oxaliplatin. Biochemical Pharmacology, 2010, 79 (8), pp.1108. 10.1016/j.bcp.2009.12.002 . hal-00565098

\section{HAL Id: hal-00565098 https://hal.science/hal-00565098}

Submitted on 11 Feb 2011

HAL is a multi-disciplinary open access archive for the deposit and dissemination of scientific research documents, whether they are published or not. The documents may come from teaching and research institutions in France or abroad, or from public or private research centers.
L'archive ouverte pluridisciplinaire HAL, est destinée au dépôt et à la diffusion de documents scientifiques de niveau recherche, publiés ou non, émanant des établissements d'enseignement et de recherche français ou étrangers, des laboratoires publics ou privés. 


\section{Accepted Manuscript}

Title: Increased levels and defective glycosylation of MRPs in ovarian carcinoma cells resistant to oxaliplatin

Authors: Giovanni Luca Beretta, Valentina Benedetti, Giacomo Cossa, Yehuda G.A. Assaraf, Eran Bram, Laura Gatti, Elisabetta Corna, Nives Carenini, Donato Colangelo,

Stephen B. Howell, Franco Zunino, Paola Perego

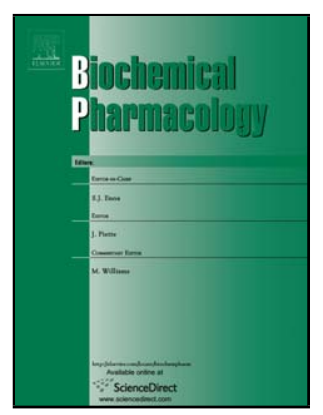

PII:

S0006-2952(09)01059-4

DOI: doi:10.1016/j.bcp.2009.12.002

Reference: BCP 10398

To appear in: $\quad B C P$

Received date: $\quad 9-10-2009$

Revised date: $\quad 1-12-2009$

Accepted date: $\quad$ 2-12-2009

Please cite this article as: Beretta GL, Benedetti V, Cossa G, Assaraf YGA, Bram E, Gatti L, Corna E, Carenini N, Colangelo D, Howell SB, Zunino F, Perego P, Increased levels and defective glycosylation of MRPs in ovarian carcinoma cells resistant to oxaliplatin, Biochemical Pharmacology (2008), doi:10.1016/j.bcp.2009.12.002

This is a PDF file of an unedited manuscript that has been accepted for publication. As a service to our customers we are providing this early version of the manuscript. The manuscript will undergo copyediting, typesetting, and review of the resulting proof before it is published in its final form. Please note that during the production process errors may be discovered which could affect the content, and all legal disclaimers that apply to the journal pertain. 


\section{Increased levels and defective glycosylation of MRPs in ovarian carcinoma}

\section{cells resistant to oxaliplatin}

Giovanni Luca Beretta ${ }^{\mathrm{a}, \mathrm{b}}$, Valentina Benedetti ${ }^{\mathrm{a}, \mathrm{b}}$, Giacomo Cossa ${ }^{\mathrm{a}}$, Yehuda G. A. Assaraf ${ }^{\mathrm{c}}$, Eran Bram ${ }^{\mathrm{c}}$, Laura Gatti ${ }^{\mathrm{a}}$, Elisabetta Corna ${ }^{\mathrm{a}}$, Nives Carenini ${ }^{\mathrm{a}}$, Donato Colangelo ${ }^{\mathrm{d}}$, Stephen B. Howell ${ }^{\mathrm{e}}$, Franco Zunino and Paola Perego ${ }^{\mathrm{a}, *}$

${ }^{\mathrm{a} D e p a r t m e n t}$ of Experimental Oncology and Laboratories, Fondazione IRCSS Istituto Nazionale Tumori, Via Venezian 1, 20133 Milan, Italy.

For e-mail address of each author: name.surname@istitutotumori.mi.it ${ }^{b}$ equal contribution

${ }^{\mathrm{c}}$ The Fred Wyszkowski Cancer Research Laboratory, Department of Biology, Technion-Israel Institute of Technology, Haifa 32000 Israel; e-mail: assaraf@tx.technion.ac.il, eranbram@techunix.technion.ac.il

${ }^{\mathrm{d}}$ Università del Piemonte Orientale, Via Solaroli 17, 28100 Novara, Italy, e-mail: donato.colangelo@med.unipmn.it

${ }^{\mathrm{e}}$ Department of Medicine and the Rebecca and John Moores Cancer Center, University of California at San Diego, Moores UCSD Cancer Center 3855 Health Sciences Drive La Jolla, California, USA e-mail: showell@ucsd.edu

Category: Antibiotics and Chemotherapeutics

"Corresponding author: Paola Perego, Department of Experimental Oncology and Laboratories, Fondazione IRCSS Istituto Nazionale Tumori, via Venezian 1, 20133 Milan, Italy; e-mail: paola.perego@istitutotumori.mi.it 


\section{ABSTRACT}

Pt compounds still represent the mainstay of the treatment of ovarian carcinoma. The aim of the present study was to investigate the molecular bases of resistance to Pt drugs using an oxaliplatin-resistant ovarian carcinoma cell model IGROV-1/OHP. These cells exhibited high levels of resistance to oxaliplatin, cross-resistance to cisplatin and topotecan and displayed a marked accumulation defect of $\mathrm{Pt}$ drugs. This feature was associated with increased expression and altered N-linked glycosylation of ATP binding cassette transporters MRP1 and MRP4. Pre-treatment with tunicamycin, which inhibits the biosynthesis of N-linked oligosaccharides, decreased the accumulation of Pt in sensitive cells exposed to oxaliplatin or cisplatin and increased the electrophoretic mobility of MRP1 and MRP4, reproducing the association between decreased glycosylation of MRP1 and MRP4 and decreased Pt accumulation observed in the resistant IGROV-1/OHP cells. The observed N-glycosylation defect of oxaliplatin-resistant cells was linked to reduced levels of $\mathrm{N}$-acetylglucosamine-1phosphotransferase (GNPTG) and mannosyl (alpha-1,6-)-glycoprotein beta-1,6-N-acetylglucosaminyltransferase (MGAT5). This feature, observed in IGROV-1/OHP cells, was associated with decreased retention of Pt drugs. In addition, the over-expression of fully glycosylated MRP1 or MRP4 in tumor cell line of ovarian origin was associated with resistance to oxaliplatin and cisplatin. Our findings, showing that development of resistance to oxaliplatin results in up-regulation of MRPs, support that patients with oxaliplatin-refractory ovarian carcinomas may benefit from non-Pt based regimens which do not contain MRP1 and MRP4 substrates.

Key words: oxaliplatin, ovarian carcinoma, ABC transporters, cellular resistance, MRP4. 


\section{INTRODUCTION}

Platinum (Pt) drugs are employed in a wide range of solid tumors, and represent the mainstay of the first-line therapy of ovarian carcinoma [1]. In spite of the remarkable clinical success of Pt-based therapies, the emergence of drug resistance during therapy is a major cause of treatment failure [1]. Development of non-cross-resistant analogs of cisplatin and carboplatin has generated a large number of compounds among which oxaliplatin (trans, 1, 1,2-diaminocyclohexane oxalato Pt II) has been approved for clinical use [2]. In preclinical studies, oxaliplatin has shown activity in some cisplatin-resistant cell lines with acquired resistance and in inherently cisplatin-resistant colorectal cancers [3]. The capability of oxaliplatin to overcome cisplatin resistance in preclinical models is not a general feature and the cross-resistance between cisplatin and oxaliplatin has been reported to be dependent on the levels of cisplatin resistance. A cross-resistance has been observed in low-level resistance models while less cross-resistance has been reported in models with high (>10-fold) level resistance [4]. Oxaliplatin has activity and a favorable pharmacological profile in epithelial ovarian cancer as well [5]. Oxaliplatin and cisplatin exhibit different sensitivity profiles indicating differences in drug-DNA interaction and/or cellular response or detoxification [6]. For example, oxaliplatin produces fewer adducts than cisplatin and is able to overcome low level of cisplatin resistance associated with loss of DNA mismatch repair [7,8]. However, it is likely that differences in the influx or efflux mechanisms for these drugs also contribute to their unique patterns of clinical activity. For example, organic cation transporters have been proposed as determinants of oxaliplatin, but not cisplatin accumulation and cytotoxicity [9]. Extensive studies on resistance to cisplatin have demonstrated that it is multi-factorial in nature. Indeed, the determinants of the reduced efficacy of antitumour therapy include a) tumour-related factors, such as the activation of drug resistance mechanisms by tumour cells; b) drug-related factors, such as inadequate intratumour concentration of the drug and tumour- 
microenviroment interactions (e.g., hypoxia, microvesicle release) [10]. Cellular alterations of drug-resistant cells involve enhanced activity of detoxification mechanisms (e.g., increased detoxification by thiols), alterations in repair mechanisms (e.g., enhanced repair or increased DNA damage tolerance) and in the cellular response to DNA damage (e.g., DNA mismatch repair defects, reduced susceptibility to apoptosis) and alterations of survival pathways $[11,12,13]$. Acquired resistance to platinum compounds has been recently related to restoration of BRCA1/2 expression and homologous recombination function in tumors with frame-shift mutations of such genes [14]. Cells that have acquired resistance to cisplatin often have impaired drug uptake [15] and this has been linked to altered expression of genes involving copper metabolism [16-21]. Additional studies have implicated members of the ATP binding cassette $(\mathrm{ABC})$ family of transporters such as Multidrug resistance associated protein (MRP) 2 and MRP1 in the accumulation defects found in cisplatin-resistant cells $[22,23]$. Based on similarity to other members of this family [24], it is likely that other ABC transporters are involved in regulating sensitivity to the Pt compounds. Since conventional cytotoxic drugs still represent the mainstay of antitumor therapy, the current study was designed to explore the molecular bases of resistance to the Pt drugs with particular reference to impaired accumulation using an ovarian carcinoma cell line selected in vitro for high level resistance to oxaliplatin and characterized by cross-resistance to clinically relevant cytotoxic agents. In fact, these IGROV-1/OHP cells also exhibited cross-resistance to cisplatin and markedly reduced $\mathrm{Pt}$ drug accumulation.

Our findings show that decreased Pt drug accumulation was associated with a defect in $\mathrm{N}$-glycosylation involving $\mathrm{ABC}$ transporters as well as increased expression of MRP4 and MRP1. We provide evidence that, although in selected conditions, overexpression of MRP1 or MRP4 in tuomor cells of ovarian origin results in acquisition of resistance to Pt drugs. 
Thus, the increased expression of $\mathrm{ABC}$ transporters in Pt drug resistant cells may contribute to the multidrug resistant phenotype of the generated models.

\section{MATERIALS AND METHODS}

\subsection{Cell lines and cell sensitivity to drugs}

The human ovarian carcinoma cell lines IGROV-1, IGROV-1/OHP, 2008 and the osteosarcoma U2-OS (ATCC, HTB 96) cell line were used in this study [13,25]. The resistant variant, IGROV-1/OHP, was selected by exposure of IGROV-1 cells to increasing oxaliplatin concentrations starting from $0.7 \mu \mathrm{g} / \mathrm{ml}$. When cells showed suffering marks, the drug was removed. This step was repeated till cells were capable to growth in the presence of $0.7 \mu \mathrm{g} / \mathrm{ml}$ oxaliplatin. Cells were then exposed to increasing drug concentrations up to $10 \mu \mathrm{g} / \mathrm{ml}$. When IGROV-1/OHP cells were grown in the absence of oxaliplatin, resistance was stable for at least 6 months. Cell growth rates were similar (doubling time: $22 \mathrm{~h}$ for IGROV-1, $25 \mathrm{~h}$ for IGROV-1/OHP). Cell sizes and morphology were also similar between parental and resistant cells. IGROV-1 and IGROV-1/OHP cells were cultured in RPMI-1640 medium (BioWhitaker, Verviers, Belgium) supplemented with 10\% fetal bovine serum (Invitrogen Italia, San Giuliano Milanese, Italy), whereas the U2-OS cell line was grown in Mc Coy's 5A medium supplemented with $10 \%$ fetal calf serum. U2-OS transfected cells were cultured in the presence of G418 (400 $\mu \mathrm{g} / \mathrm{ml}$; Calbiochem, San Diego, CA, USA). The cell sensitivity to drugs was measured by using a growth-inhibition assay based on cell counting [26]. Exponentially growing cells $\left(25000\right.$ cells $\left./ \mathrm{cm}^{2}\right)$ were seeded in duplicate into six-well plates and exposed to drug $24 \mathrm{~h}$ later. After $1 \mathrm{~h}$ of drug incubation, the medium was replaced with fresh medium and cells were harvested $72 \mathrm{~h}$ later for counting with a cell counter. When 
assaying cell sensitivity to 6-mercaptopurine (Sigma-Aldrich, Milan, Italy), treatment was for $72 \mathrm{~h}$ and cells were counted at the end of treatment. $\mathrm{IC}_{50}$ is defined as the drug concentration producing 50\% decrease of cell growth. At least 3 independent experiments were performed for each drug or type of treatment.

\subsection{Drug accumulation studies}

Exponentially growing cells $\left(32000\right.$ cells $\left./ \mathrm{cm}^{2}\right)$ were seeded in $5 \mathrm{~cm}$ diameter dishes in triplicate and, $48 \mathrm{~h}$ later, they were exposed to cisplatin or oxaliplatin for different times (30, 60 or $120 \mathrm{~min}$ ) for time course experiments or for $1 \mathrm{~h}$ in case of dose response curves. Different concentrations including the $\mathrm{IC}_{50}$ and the $\mathrm{IC}_{80}$ of both cell lines were selected because they produce an effect on proliferation which can be measured $72 \mathrm{~h}$ after the end of the $1 \mathrm{~h}$ treatment. Therefore, such concentrations are pharmacologically relevant in in vitro tests. When assessing the effect of tunicamycin on drug accumulation, cells were incubated for $24 \mathrm{~h}$ with $0.2 \mu \mathrm{g} / \mathrm{ml}$ tunicamycin (Sigma-Aldrich), and then for $1 \mathrm{~h}$ with $300 \mu \mathrm{M}$ cisplatin or oxaliplatin. After treatment with Pt drugs, cell monolayers were washed with ice-cold PBS, scraped, harvested and dissolved in $1 \mathrm{~N} \mathrm{NaOH}$ [27]. When analyzing Pt drug efflux, cells were exposed to cisplatin or oxaliplatin for 15 min and, after washing with ice-cold PBS, they were incubated for different times in drug-free medium before harvesting for analysis of residual accumulated Pt. Residual accumulation after 15 min drug exposure was evaluated using a drug concentration which allows detection of Pt in resistant cells without direct damage to sensitive cells. Total cellular Pt content was determined by flameless atomic absorption spectroscopy (Model 3300, Perkin Elmer). Cellular Pt levels were expressed as $\mathrm{ng} / 10^{6}$ cells, with cell number determined by counting parallel cultures. For each type of treatment at least 3 independent experiments were performed. Accumulation of the fluorescent compound rhodamine 123 in IGROV-1 and IGROV-1/OHP cells was assessed as 
described by Shen et al. [28]. Briefly, cells were incubated with $0.3 \mu \mathrm{M}$ rhodamine 123 for incubation times ranging from 0 to 60 min and analysed using a FACScan (Becton Dickinson Italia SpA, Buccinasco, Italy).

\subsection{Western blot analysis}

Western blot analysis was carried out as described previously [29]. Briefly, samples $(40 \mu \mathrm{g})$ were fractionated by SDS-PAGE and blotted on nitrocellulose membranes. Blots were pre-blocked in PBS containing 5\% (w/v) dried non fat milk and then incubated overnight at $4{ }^{\circ} \mathrm{C}$ with antibodies to BCRP [30], MRP1 (Alexis Biochemicals, San Diego, CA), MRP2 [30], MRP3 [30] and MRP4 (Monosan, Valter Occhiena, Torino, Italy), GNPTG and $\beta 5$ integrin (Abcam, UK), MGTA5 (Abnova, LiStarfish, cernusco sul Naviglio, Italy). Anti-tubulin antibody (Sigma Chemicals Co., St. Louis, MO) or anti $\mathrm{Na}^{+} / \mathrm{K}^{+}$ATPase antibody [30] were used to control for loading. Antibody binding to blots was detected by chemiluminescence (Amersham Pharmacia Biotech., Cologno Monzese, Italy). Three independent experiments were performed.

\subsection{Analysis of glycosylation of ABC transporters}

Different endoglycosidases were used to remove sugar residues from the transporters in IGROV-1 cells. Exponentially growing cells were harvested and protein lysates were obtained both in native and denaturing conditions as described in manufacturer's protocol (EDEGLY Enzymatic Protein Deglycosylation Kit, Sigma). The extracts were treated with PNGase F, O-glycosidase, sialidase A, $\beta$-N-acetylglucosaminidase and $\beta$-1,4-galactosidase at $37^{\circ} \mathrm{C}$ for $3 \mathrm{~h}$. Western blot analysis was used to evaluate the glycosylation status of $\mathrm{ABC}$ transporters as described above. 


\subsection{MRP4 and MRP1 knockdown}

Synthetic small interfering RNAs (siRNAs, Stealth ${ }^{\mathrm{TM}}$, Invitrogen) were used to knockdown MRP4 (5'-AAAUAGUUAAGUCGAGGGCUGUCC-3') and MRP1 (5'UCAAUGgGaUCAAAGUGCUAAAGCU-3') gene expression. Preliminary experiments were performed to define optimal siRNA concentrations and exposure times. The transfection efficiency was $\sim 80 \%$, as determined by AlexaFluor Red labeled siRNA (Invitrogen). The efficiency of down-regulation of target expression was monitored by Western blotting. Exponentially growing cells were seeded in six-well plates and when sub-confluent, they were transfected with $100 \mathrm{nM}$ MRP4 Stealth Select siRNA or control siRNA (MedGC RNAi negative control) using Lipofectamine RNAimax (1.5 $\mu 1 /$ well, Invitrogen). For each well, 100 $\mu 1$ of vehicle-siRNA mix prepared in Optimem I (Invitrogen) was added to $0.5 \mathrm{ml}$ of serumcontaining medium for $5 \mathrm{~h}$, and then medium was replaced with fresh medium. Twenty $\mathrm{h}$ later, cells were harvested and seeded for drug accumulation/efflux experiments or cell determination of sensitivity to oxaliplatin. Parallel cultures were used to assess the efficiency of knockdown of the target gene by Western blot analysis. Accumulation and efflux studies were performed $48 \mathrm{~h}$ post-transfection as detailed above. Cell sensitivity was determined as described above in cells exposed for $1 \mathrm{~h}$ to oxaliplatin. At least 3 independent experiments were performed.

\subsection{Overexpression of MRP4 and MRP1}

U2-OS, IGROV-1 and 2008 cells were stable transfected with pCMV6-Neo containing MRP1 and MRP4 (Origene, Rockville, MD) using Lipofectamine 2000 (Invitrogen) according to the manufacturer's protocol. Cells were seeded in 6-well plates and $24 \mathrm{~h}$ after seeding DNA plasmids and transfection reagent were added. Stable transfectants were selected using G418 and G418-resistant cells were picked for further analysis. 


\subsection{Immunofluorescence analysis}

U2-OS cells were plated on coverslips and $24 \mathrm{~h}$ after seeding were fixed in $3 \%$ paraformaldehyde, permeabilized with $100 \%$ cool methanol, and incubated with the antiMRP1 (dilution: 1:50) or MRP4 (dilution: 1:50) antibodies (Alexis Biochemicals, Monosan) overnight at $4{ }^{\circ} \mathrm{C}$. After washing with PBS, cells were incubated with a goat anti-rat IgG Alexa Fluor 488-conjugated antibody (dilution: 1:200) (Molecular Probes/Invitrogen) for $1 \mathrm{~h}$ at room temperature and then stained with Hoechst 33342. Coverslips were mounted in Mowiol and observed using an upright fluorescence microscope (Leica DMRB; Leica Microsystems) equipped with a CCD and analyzed with the IAS2000 software (Delta Sistemi).

\subsection{Sequencing of putative N-glycosylation sites of MRP4}

Bioinformatic tools available at www.expasy.ch were used to predict N-glycosylation sites of MRP4 and specific primers were designed to analyze the possible occurrence of mutations at those sites. cDNA from IGROV-1 and IGROV-1/OHP cells was obtained as described above. The designed primers (forward primer: 5'-ataatgaggaaagtgaacaacctc-3'; reverse primer: 5'-ttcagaattgactcaaacattttgtt-3') were used to amplify the MRP4 cDNA. PCR conditions were as follows: initial denaturation at $95^{\circ} \mathrm{C}$ for $2 \mathrm{~min}$, followed by 30 cycles at $95^{\circ} \mathrm{C}$ for $30 \mathrm{sec}, 55^{\circ} \mathrm{C}$ for $30 \mathrm{sec}, 68^{\circ} \mathrm{C}$ for $2 \mathrm{~min}$, and finally $68^{\circ} \mathrm{C}$ for $5 \mathrm{~min}$. The same primers were used to sequence the amplified products.

\subsection{Statistical analysis}


The results are presented as means \pm SD. Statistical analysis was performed using GraphPad PRISM 4.0 (GraphPad Software Inc., San Diego, CA). We used a two-way ANOVA for comparisons. We considered values as significant when $P$ was $<0.05$.

\section{RESULTS}

\subsection{Cells resistant to oxaliplatin are cross-resistant to cisplatin, topotecan and 6- mercaptopurine}

The human ovarian carcinoma cell line IGROV-1/OHP was generated by repeated exposure of the ovarian IGROV-1 cell line to increasing concentrations of oxaliplatin. As shown in Table 1, the IGROV-1/OHP cells were 73-fold resistant to oxaliplatin and displayed 18-fold cross-resistance to cisplatin. A marked resistance to oxaliplatin was also supported by colony forming assays (Supplementary Figure 1A). IGROV-1/OHP cells were also 10-fold cross-resistant to the DNA topoisomerase I inhibitor topotecan and 3.8-fold cross resistant to 6-mercaptopurine, whereas resistance to the DNA topoisomerase II inhibitors etoposide and doxorubicin was low. A phenotypic characterization of IGROV-1/OHP cells indicated lower levels of apoptosis than in IGROV-1 cells after exposure to platinum drugs as shown by Annexin V binding, TUNEL assays and analyses of cleavage of caspases (Supplementary Table 1, Supplementary Figure 1B). In addition, when Ki67 was used as a marker of proliferation, immunofluorescence analysis of Ki67 levels in sensitive and resistant cells exposed to equitoxic concentrations of platinum drugs $\left(\mathrm{IC}_{80}\right)$ indicated that treatment reduced the fraction of positive cells (Supplementary Table 2). Biochemical analyses of components of the apoptotic pathway showed that both sensitive and resistant cells expressed TRAIL-R1 and TRAIL-R2, components of the extrinsic apoptotic pathway (Supplementary Table 2). No 
activation of caspase 9 was detected in resistant cells together with a decreased activation of caspase 8 (Supplementary Figure 1B).

Moreover, an investigation of biomarkers of angiogenesis, i.e. VEGF and PDGF, indicated that acquisition of resistance to oxaliplatin, associated with p53 mutation [13] and protein stabilization resulted in reduced expression of VEGF and lack of induction by drug treatment. In addition, an up-regulation of PDGF-A and -B was observed in both cell lines after oxaliplatin exposure (Supplementary Figure 1C)

\subsection{Resistant cells display an accumulation defect}

Since reduced drug accumulation appears to be a common defense mechanism against Pt drugs [15], we examined Pt accumulation using flameless atomic absorption spectroscopy. IGROV-1 and IGROV-1/OHP cells were exposed to 100 or $200 \mu \mathrm{M}$ oxaliplatin for 30,60 , or 120 min following which the cells were washed thoroughly and the Pt content determined. As shown in Figure 1A, the resistant subline accumulated significantly less Pt at each time point and at both of the drug concentrations tested. Impaired accumulation was also evident when cells were exposed for $1 \mathrm{~h}$ to a range of increasing oxaliplatin concentrations (Figure 1B). The accumulation of cisplatin was determined following a $1 \mathrm{~h}$ exposure to a concentration corresponding to the $\mathrm{IC}_{50}$ for the resistant cell subline $(150 \mu \mathrm{M})$. Under these conditions the IGROV-1/OHP cells accumulated $18.0 \pm 0.8( \pm \mathrm{SD}) \mathrm{ng} \mathrm{Pt} / 10^{6}$ cells whereas the parental cells accumulated $43.8 \pm 1.1$ ( $\pm \mathrm{SD}) \mathrm{ng} \mathrm{Pt} / 10^{6}$ cells $(\mathrm{P}<0.05$, ANOVA). Reduced accumulation of Pt drugs was not associated with a generalized defect in accumulation of small molecules, as assessed using the fluorescent compound rhodamine 123 [28]. In fact, both cell lines displayed similar rates of rhodamine 123 accumulation (data not shown). Thus, development of resistance to oxaliplatin resulted in impaired accumulation of both oxaliplatin and cisplatin. 


\subsection{Efflux of oxaliplatin and cisplatin}

We examined whether the impaired accumulation of oxaliplatin and cisplatin in the IGROV-1/OHP cells was due to enhanced efflux. The parental IGROV-1 and resistant IGROV-1/OHP cells were loaded by exposure to $300 \mu \mathrm{M}$ oxaliplatin or cisplatin for $15 \mathrm{~min}$; they were then washed and the amount of Pt remaining after incubation in drug-free medium was determined every $15 \mathrm{~min}$ for up to $1 \mathrm{~h}$. Following loading with either oxaliplatin or cisplatin, the Pt content of the IGROV-1 cells decreased progressively with time. After $1 \mathrm{~h}$ the IGROV-1 cells contained only $50 \%$ of their initial load of oxaliplatin or cisplatin (Figure 1C and 1D). In contrast no significant efflux was observed from the IGROV-1/OHP cells following loading with either drug.

\subsection{Western blot analysis of levels of $\mathrm{ABC}$ transporters}

Based on prior reports indicating that some of the $\mathrm{ABC}$ transporters may be implicated in the Pt drug accumulation defect found in resistant cells [22,23], we compared the level of expression of MRP1 - MRP4 and BCRP in the IGROV-1 and IGROV-1/OHP cells (Figure 2). The MRP2, MRP3 and BCRP were not expressed in either cell type. The Western blot analysis demonstrated both an increase in MRP1 and MRP4 expression in the resistant cells and increased mobility of both proteins.

\subsection{Analysis of glycosylation of MRPs}

The increased mobility of MRP1 and MRP4 suggested a defect in glycosylation. To determine whether impaired glycosylation could produce this effect, parental IGROV-1 cells were exposed to different glycosylation inhibitors and then harvested for Western blot analysis. The IGROV-1 cells were exposed to castanospermine, swansonine and tunicamycin, which act as $\alpha$-glucosidase, $\alpha$-mannosidase and $\mathrm{N}$-linked glycosidase inhibitors, respectively. 
Castanospermine and swansonine did not modify MRP1 or MRP4 mobility (Figure 3A). However, tunicamycin, which blocks the first step in the biosynthesis of $\mathrm{N}$-linked oligosaccharides, increased MRP1 and MRP4 mobility in a manner similar to that observed in the IGROV-1/OHP cells (Figure 3A).

To further document that reduced $\mathrm{N}$-glycosylation could account for the increased mobility of MRP1 and MRP4, IGROV-1 cell lysates were treated with a variety of different endoglycosidases including PNGase $\mathrm{F}, \quad \mathrm{O}$-glycosidase, sialidase $\mathrm{A}, \quad \beta-\mathrm{N}$ acetylglucosaminidase and $\beta$-1,4-galactosidase. Treatment with sialidase A, $\beta$-Nacetylglucosaminidase and PNGase F, which removes all N-linked oligosaccharides from the asparagine residues of proteins, enhanced MRP4 migration (Figure 3B). Only PNGaseF had a clear effect on the mobility of MRP1. Among the tested enzymes, PNGase F was the enzyme that had the largest effect on MRP4 glycosylation (Figure 3B).

\subsection{Accumulation of Pt drugs in cells pretreated with tunicamycin}

To test the effect of impaired protein glycosylation on accumulation of oxaliplatin and cisplatin, the IGROV-1 and IGROV-1/OHP cells were treated with $0.2 \mu \mathrm{g} / \mathrm{ml}$ tunicamycin for $24 \mathrm{~h}$ before being exposed for $1 \mathrm{~h}$ to $300 \mu \mathrm{M}$ oxaliplatin or cisplatin (Figure 4A). Treatment with tunicamycin significantly reduced the accumulation of oxaliplatin by $58 \%$ and cisplatin by $25 \%$ in the IGROV -1 cells $(\mathrm{P}<0.05$, ANOVA). Although smaller in magnitude, a reduction was also observed in the IGROV-1/OHP cells $(\mathrm{P}<0.05$, ANOVA). Thus, the reduced $\mathrm{Pt}$ accumulation phenotype observed in the IGROV-1/OHP cells could be reproduced in the IGROV-1 cells by interfering with glycosylation.

\subsection{Effect of knockdown of MRP4 on Pt drug accumulation}


To further examine the contribution of MRP4 to the accumulation of oxaliplatin and cisplatin, MRP4 expression was reduced in the IGROV-1 cells by transient transfection of a siRNA duplex. Transfection of the siRNA duplex targeting the MRP4 mRNA reduced the level of MRP4 protein to almost undetectable levels (Figure 4B). As shown in Figure 4C this was associated with a $31 \%$ increase in the accumulation of oxaliplatin, and a $36 \%$ increase in the accumulation of cisplatin, when the cells were exposed to these drugs at a concentration of $300 \mu \mathrm{M}$ drug for $15 \mathrm{~min}$.

\subsection{Effect of knockdown of MRP4 on cell sensitivity}

To establish whether MRP4 was indeed involved in resistance to oxaliplatin, we examined the effect of knocking down MRP4 expression on sensitivity to the cytotoxic effect of oxaliplatin in the resistant IGROV-1/OHP cells. As shown in Figure 4D, knockdown of MRP4 increased sensitivity to the antiproliferative effect of oxaliplatin; the $\mathrm{IC}_{50}$ was reduced from $921 \pm 5$ ( \pm SD) to $459 \pm 2( \pm \mathrm{SD}) \mu \mathrm{M}$ (ANOVA $\mathrm{p}<0.05)$

\subsection{Effect of knockdown of MRP1 on Pt drug accumulation and cell sensitivity}

Transient transfection of a siRNA duplex targeting MRPI mRNA was also used to examine the contribution of MRP1 expression to the accumulation of oxaliplatin and cisplatin. As shown in Figure 5A, the siRNA reduced the level of MRP1 protein to almost undetectable levels. No change in oxaliplatin and cisplatin accumulation was observed in IGROV-1 cells transfected with siRNA targeting MRPI (Figure 5B). Thus, unlike MRP4, MRP1 does not appear to modulate sensitivity to oxaliplatin in IGROV-1/OHP cells under our experimental conditions (Figure 5C).

\subsection{Overexpression of MRP4 and MRP1}


To further examine the role of MRP1 and MRP4 in drug resistance, mammalian expressing vectors carrying the transporters were used to transfect IGROV-1 and 2008 ovarian carcinoma cell lines. No stable transfectants of IGROV-1 cells were obtained for MRP4. MRP1 overexpression was achieved in IGROV-1 cells and was maintained for a period of time allowing us to perform cell sensitivity assays (Figure 6A). In 2008 cells, stable transfectants of MRP4 were obtained (Figure 6A). A persistent overexpression of both transporters was achieved only in the highly transfectable U2-OS cell line (Figure 6B). Thus, we used all these cell models to clarify whether MRP1 and MRP4 are involved in regulating drug sensitivity. As reported in Table 2, MRP1 and MRP4 overexpressing U2-OS cells were slightly resistant to topotecan and 6-mercaptopurine. No change in cellular sensitivity to oxaliplatin and cisplatin was observed. Interestingly, overexpression of MRP1 in IGROV-1 cells resulted in resistance to oxaliplatin, 6-mercaptopurine and topotecan (Table 3). An important resistance to oxaliplatin and cisplatin was observed in MRP4 overexpressing 2008 ovarian cancer cells (Table 4).

\subsection{Sequencing of putative N-glycosylation sites of MRP4 and expression of selected glycosyltransferases}

Although the low spontaneous mutation frequency is unlikely to generate mutations in the potential $\mathrm{N}$-glycosylation sites in $M R P 4$, oxaliplatin is quite mutagenic to mammalian cells [31] and such mutations may have arisen during the selection process. To determine whether mutation of the $\mathrm{N}$-glycosylation sites in MRP4 could account for the observed glycosylation defect, we sequenced the putative glycosylation sites with primers designed using web available tools. However, no mutations were found in the 4 asparagine residues (N651, N746, N754 and N792) in MRP4. 
In an attempt to better understand the bases of the N-glycosylation defect of oxaliplatin-resistant cells, we examined whether it involved other cellular proteins not belonging to the $\mathrm{ABC}$ transporters system. We found that IGROV-1/OHP cells exhibited a defect in the glycosylation of the cell surface receptor $\beta 5$ integrin (Figure 7). Western blot analyses of selected glycosyltransferase supported that the IGROV-1/OHP glycosylation defects were linked to reduced levels of N-acetylglucosamine-1-phosphotransferase (GNPTG), an enzyme involved in the initial step of the biosynthesis of $\mathrm{N}$-glycans and of mannosyl (alpha-1,6-)-glycoprotein beta-1,6-N-acetyl-glucosaminyltransferase (MGAT5) (Figure 7). The expression levels of these glycosyltransferases were similar in the IGROV-1 ovarian carcinoma cells and in the U2-OS cells (data not shown).

\section{DISCUSSION}

Since conventional cytotoxic agents still represent the mainstay of antitumor therapy, the present study was designed to define the biochemical and cellular bases of resistance to antitumor drugs with particular reference to Pt compounds, taking advantage of a model system exhibiting a multidrug-resistant phenotype. Resistance to platinum compounds in IGROV-1/OHP cells was associated with reduced susceptibility to drug-induced apoptosis, as shown by quantitative measurements of apoptotic cells and by analyses of cleavage of caspases of the intrinsic and extrinsic apoptotic pathways. In the ovarian carcinoma subline selected for resistance to oxaliplatin and characterized by defects in drug accumulation, we found that increased levels of MRP1 and MRP4 in resistant cells were associated with a glycosylation defect which involves N-linked oligosaccharides. Since no significant efflux was observed in resistant cells following loading with cisplatin and oxaliplatin, the 
mechanisms leading to reduced intracellular content of both drugs are expected to act very early upon drug exposure, as already reported for Gp170 [24]. The electrophoretic mobility of MRP1 and MRP4 was altered in cells selected for resistance to oxaliplatin, and inhibition of the synthesis of N-linked sugars or removal of such sugars with endogylcosidases reproduces this effect. Similarly, $\beta 5$ integrin also showed glycosylation defects in IGROV-1/OHP cells. This behaviour, observed in different glysosylated proteins of resistant cells, was linked to reduced levels of two glycosyltransferases, i.e., N-acetylglucosamine-1-phosphotransferase (GNPTG) and of mannosyl (alpha-1,6-)-glycoprotein beta-1,6-N-acetylglucosaminyltransferase (MGAT5). Interestingly, an analysis of MRP1 and MRP4 mRNA levels using Real time PCR (data not shown), indicated that increased levels of the two proteins were not directly related to the mRNA levels as only for MRP4 a slight increase (1.7fold) in the transcript level was observed in resistant cells.

Knockdown of MRP4 but not of MRP1 expression modulated both the accumulation of oxaliplatin and sensitivity to its cytotoxic effects. In addition, the over-expression of fully glycosylated MRP4 or MRP1 in tumor cell lines of ovarian origin was associated with resistance to Pt drugs. An association between increased expression of MRP1 and resistance to cisplatin has been previously reported in a panel of lung cancer cell lines not selected in vitro for drug resistance [32], but no evidence of resistance to Pt drugs in cells overexpressing exogenous MRP1 has been provided [33]. In the present study, the employed gain of function approach suggests that, at least in ovarian carcinoma models, oxaliplatin and cisplatin are substrates for MRP1 and MRP4, which appear to transport also topotecan, a known MRP4 substrate, and 6-mercaptopurine, one of the most important substrates of MRP4 [34-36]. Indeed, the MRP4-over-expressing IGROV-1/OHP cells were found to be cross-resistant to topotecan and to 6-mercaptopurine. Thus, selection for resistance to oxaliplatin resulted in alterations conferring a multi-drug resistant phenotype involving cisplatin and the non-Pt drug 
topotecan and 6-mercaptopurine. It remains to be defined whether glycosylation defective forms of MRPs can provide the capability to transport different substrates. Indeed, although using a loss of function approach we could not selectively knockdown only the fully glycosylated form of MRP4, our results suggest a possible relevance of the glycosylated defective transporter in cellular resistance to Pt drugs.

The fact that both inhibition of glycosylation with tunicamycin and removal of $\mathrm{N}$ linked sugars with endoglycosidases in parental cells, reproduced the glycosylation defects observed in IGROV-1/OHP cells, supports the occurrence of a defective $\mathrm{N}$-glycosylation in Pt-resistant cells. In addition, since IGROV-1/OHP cells are not null for MRP4 and MRP1 glycosylation and fully glycosylated transporters are detectable in Western blot, the small changes in Pt-drug accumulation observed in tunicamycin treated resistant cells are the result of an additional increase of deglycosylated transporters. Our results confirm and extend previous observations from other laboratories showing that altered glycosylation of MRP1 is found in cells selected for resistance to the Pt drugs [23], and further suggests a link between defective $\mathrm{N}$-glycosylation of MRPs and drug resistance. In addition, findings relative to the role of glycosylation in determining access to the extracellular domains of human MRP1 have already been reported, although no evidences that glycosylation really alters its activity as a transporter have been provided [37]. The observation that treatment of the parental IGROV-1 cells with tunicamycin reproduced the change in mobility and reduced the accumulation of both oxaliplatin and cisplatin supports the concept that when not fully glycosylated MRP4 may enhance efflux of these drugs. Recent reports indicate that other transporters of the ABC superfamily can exhibit glycosylation defects that result in altered localization [23,38]. At present, the conclusive significance of such post-translational modifications is poorly elucidated and controversial data have been reported $[39,40]$. 
The finding that the levels of $\mathrm{ABC}$ transporters are increased in cells selected for resistance to oxaliplatin indicates that oxaliplatin-resistant cells acquire molecular features that can result in increased resistance also to non Pt-based agents. This feature may have relevant clinical implications in the optimization of the treatment of ovarian carcinoma, because these MRPs may serve to reduce access of other drugs to critical intracellular targets, thus contributing to the multi-drug resistant phenotype. In addition, since MRP4 has been implicated in cell signalling pathways [41], it is conceivable that inactivation of MRP4 increases sensitivity to Pt drugs by affecting cellular factors unrelated to drug transport.

Our results support the conclusion that repeated exposure of the parental cells to oxaliplatin resulted in selection of cells expressing high level of resistance to oxaliplatin as well as cross-resistance to cisplatin, topotecan, and 6-mercaptopurine. Although this phenotype was associated with changes in the level of expression and electrophoretic mobility of MRP1 and MRP4, this feature may be only one of the resistance mechanisms to oxaliplatin that operate in the resistant cells. This interpretation is supported by the evidence that MRP4 knockdown in IGROV-1/OHP cells did not modulate Pt accumulation under our experimental conditions. The role of MRP1 and MRP4 in resistance to Pt compounds appears dependent on the cellular context as overexpression in osteosarcoma cells did not confer resistance to oxaliplatin and cisplatin. However, a recent report showing that MRP1 is an adverse marker for the outcome of ovarian carcinoma patients supports the relevance of the transporters in ovarian carcinoma aggressiveness [42].

Overall, these findings may have relevance to the design of therapeutic strategies. Since the development of resistance to oxaliplatin can result in up-regulation of MRPs, patients with oxaliplatin-refractory ovarian carcinomas may benefit from non-Pt based regimens which do not contain MRP1 and MRP4 substrates. 
1

\section{Acknowledgements}

This work was supported by Associazione Italiana per la Ricerca sul Cancro and Ministero della Salute and by the European Community grant CHEMORES. We thank Mrs. Enrica Favini for technical support. 


\section{REFERENCES}

[1]. Herzog TJ. The current treatment of recurrent ovarian cancer. Curr Oncol Rep 2006; $8: 448-54$

[2]. Misset JL, Bleiberg H, Sutherland W, Bekradda M, Cvitkovic E. Oxaliplatin clinical activity: a review. Crit Rev Oncol Hematol 2000; 35:75-93.

[3]. Raymond E, Chaney SG, Taamma A, Cvitkovic E. Oxaliplatin: a review of preclinical and clinical studies. Ann Oncol 1998; 9:1053-71.

[4]. Stordal B, Pavlakis N, Davey R. Oxaliplatin for the treatment of cisplatin-resistant cancer: a systematic review. Cancer Treat Rev. 2007; 33:347-57.

[5]. Fu S, Kavanagh JJ, Hu W, Bast RC Jr. Clinical application of oxaliplatin in epithelial ovarian cancer. Int J Gynecol Cancer 2006; 16:1717-32.

[6]. Rixe O, Ortuzar W, Alvarez M, Parker R, Reed E, Paull K, et al. Oxaliplatin, tetraplatin, cisplatin, and carboplatin: spectrum of activity in drug-resistant cell lines and in the cell lines of the National Cancer Institute's Anticancer drug screen panel. Biochem Pharmacol 1996; 52:1855-65.

[7]. Woynarowski JM, Faivre S, Herzig MC, Arnett B, Chapman WG, Trevino AV, et al. Oxaliplatin-induced damage of cellular DNA. Mol Pharmacol 2000; 58:920-7.

[8]. Fink D, Nebel S, Aebi S, Zheng H, Cenni B, Nehmè A, et al. The role of DNA mismatch repair in platinum drug resistance. Cancer Res 1996; 56:4881-6.

[9]. Zhang S, Lovejoy KS, Shima JE, Lagpacan LL, Shu Y, Lapuk A, et al. Organic cation transporters are determinants of oxaliplatin cytotoxicity. Cancer Res 2006; 66:8847-57.

[10]. Agarwal R, Kaye SB. Ovarian cancer: strategies for overcoming resistance to chemotherapy. Nat Rev Cancer 2003; 3:502-16. 
[11]. Manic S, Gatti L, Carenini N, Fumagalli G, Zunino F, Perego P. Mechanisms controlling sensitivity to platinum complexes: role of p53 and DNA mismatch repair. Curr Cancer Drug Targets 2003; 3:21-9.

[12]. Cossa G, Gatti L, Zunino F, Perego P. Strategies to improve the efficacy of platinum compounds. Curr Med Chem 2009; 16:2355-65.

[13]. Benedetti V, Perego P, Beretta GL, Corna E, Tinelli S, Righetti SC, et al. Modulation of serviva pathways in ovarian carcinoma cell lines resistant to platinum compounds. Mol Cancer Ther 2008; 7:679-87.

[14]. Wang W, Figg WD. Secondary BRCA1 and BRCA2 alterations and acquired chemoresistance. Cancer Biol Ther 2008; 7:1004-5.

[15]. Gately DP, Howell SB. Cellular accumulation of the anticancer agent cisplatin: a review. Br J Cancer 1993; 67:1171-6.

[16]. Ishida S, Lee J, Thiele DJ, Herskowitz I. Uptake of the anticancer drug cisplatin mediated by the copper transporter Ctr1 in yeast and mammals. Proc Natl Acad Sci USA 2002; 99:14298-302.

[17]. Katano K, Kondo A, Safaei R, Holzer A, Samimi G, Mishima M, et al. Acquisition of resistance to cisplatin is accompanied by changes in the cellular pharmacology of copper. Cancer Res 2002; 62:6559-65.

[18]. Chauhan SS, Liang XJ, Su AW, Pai-Panandiker A, Shen DW, Hanover JA, et al. Reduced endocytosis and altered lysosome function in cisplatin-resistant cell lines. $\mathrm{Br} \mathrm{J}$ Cancer 2003; 88:1327-34.

[19]. Beretta GL, Gatti L, Tinelli S, Corna E, Colangelo D, Zunino F, et al. Cellular pharmacology of cisplatin in relation to the expression of human copper transporter CTR1 in different pairs of cisplatin-sensitive and -resistant cells. Biochem Pharmacol 2004; 68:283-91. 
[20]. Holzer AK, Manorek JH, Howell SB. Contribution of the major copper influx transporter CTR1 to the cellular accumulation of cisplatin, carboplatin, and oxaliplatin. Mol Pharmacol 2006; 70:1390-4.

[21]. Safaei R, Otani S, Larson BJ, Rasmussen ML, Howell SB. Transport of cisplatin by the copper efflux transporter ATP7B. Mol Pharmacol 2008; 73:461-8.

[22]. Iida T, Kijima H, Urata Y, Goto S, Ihara Y, Oka M, et al. Hammerhead ribozyme against gamma-glutamylcysteine synthetase sensitizes human colonic cancer cells to cisplatin by down-regulating both the glutathione synthesis and the expression of multidrug resistance proteins. Cancer Gene Ther 2001; 8:803-14.

[23]. Liang XJ, Shen DW, Garfield S, Gottesman MM. Mislocalization of membrane proteins associated with multidrug resistance in cisplatin-resistant cancer cell lines. Cancer Res 2003; 63:5909-16.

[24]. Gottesman MM, Fojo T, Bates SE. Multidrug resistance in cancer: role of ATPdependent transporters. Nat Rev Cancer 2002; 2:48-58.

[25]. Perego P, Romanelli S, Carenini N, Magnani I, Leone R, Bonetti A, et al. Ovarian cancer cisplatin-resistant cell lines: multiple changes including collateral sensitivity to taxol. Ann Oncol 1998; 9:423-30.

[26]. Perego P, Beretta GL, Gatti L. Identification of determinants of sensitivity to antitumor drugs. In: Conn PM, editor. Handbook of Proteomic Methods, Humana Press; 2002, p. $319-330$.

[27]. Perego P, Caserini C, Gatti L, Carenini N, Romanelli S, Supino R, et al. A novel trinuclear platinum complex overcomes cisplatin resistance in an osteosarcoma cell system. Mol Pharmacol 1999; 55:528-34. 
[28]. Shen DW, Goldenberg S, Pastan I, Gottesman MM. Decreased accumulation of [14C]carboplatin in human cisplatin-resistant cells results from reduced energydependent uptake. J Cell Physiol 2000; 183:108-16.

[29]. Safaei R, Larson BJ, Cheng TC, Gibson MA, Otani S, Naerdemann W, et al. Abnormal lysosomal trafficking and enhanced exosomal export of cisplatin in drug-resistant human ovarian carcinoma cells. Mol Cancer Ther 2005; 4:1595-604.

[30]. Bram EE, Ifergan I, Grimberg M, Lemke K, Skladanowski A, Assaraf YG. C421 allelespecific ABCG2 gene amplification confers resistance to the antitumor triazoloacridone C-1305 in human lung cancer cells. Biochem Pharmacol 2007; 74:41-53.

[31]. Silva MJ, Costa P, Dias A, Valente M, Louro H, Bonavida MG. Comparative analysis of the mutagenic activity of oxaliplatin and cisplatin in the Hprt gene of $\mathrm{CHO}$ cells. Environ Mol Mutagen 2005; 46:104-15.

[32]. Young LC, Campling BG, Cole SP, Deeley RG, Gerlach JH. Multidrug resistance proteins MRP3, MRP1, and MRP2 in lung cancer: correlation of protein levels with drug response and messenger RNA levels. Clin Cancer Res. 2001; 7:1798-804.

[33]. Borst P, Evers R, Kool M, Wijnholds J. A family of drug transporters: the multidrug resistance-associated proteins. J Natl Cancer Inst. 2000; 92:1295-302.

[34]. Tian Q, Zhang J, Chan SY, Tan TM, Duan W, Huang M, et al. Topotecan is a substrate for multidrug resistance associated protein 4. Curr Drug Metab 2006; 7:105-18.

[35]. Belinsky MG, Guo P, Lee K, Zhou F, Kotova E, Grinberg A, et al. Multidrug resistance protein 4 protects bone marrow, thymus, spleen, and intestine from nucleotide analogue-induced damage. Cancer Res 2007; 67:262-8.

[36]. Reid G, Wielinga P, Zelcer N, De Haas M, Van Deemter L, Wijhholds J, et al. Characterization of the transport of nucleoside analog drugs by the human multidrug resistance proteins MRP4 and MRP5. Mol Pharmacol 2003; 63:1094-103. 
[37]. Muller M, Yong M, Peng XH, Petre B, Arora S, Ambudkar SV. Evidence for the role of glycosylation in accessibility of the extracellular domains of human MRP1 (ABCC1). Biochemistry 2002; 41:10123-32.

[38]. Paterson JK, Shukla S, Black CM, Tachiwada T, Garfield S, Wincovitch S, et al. Human ABCB6 localizes to both the outer mitochondrial membrane and the plasma membrane. Biochemistry 2007; 46:9443-52.

[39]. Wakabayashi-Nakao K, Tamura A, Furukawa T, Nakagawa H, Ishikawa T. Quality control of human ABCG2 protein in the endoplasmic reticulum: ubiquitination and proteasomal degradation. Adv Drug Deliv Rev. 2009; 61:66-72.

[40]. Mohrmann K, van Eijndhoven MA, Schinkel AH, Schellens JH. Absence of N-linked glycosylation does not affect plasma membrane localization of breast cancer resistance protein (BCRP/ABCG2). Cancer Chemother Pharmacol. 2005; 56:344-50.

[41]. Russel FG, Koenderink JB, Masereeuw R. Multidrug resistance protein 4 (MRP4/ABCC4): a versatile efflux transporter for drugs and signalling molecules. Trends Pharmacol Sci. 2008; 29:200-7.

[42]. Faggad A, Darb-Esfahani S, Wirtz R, Sinn B, Sehouli J, Könsgen D, et al. Expression of multidrug resistance-associated protein 1 in invasive ovarian carcinoma: implication for prognosis. Histopathology 2009, 54:657-66. 
Table 1. Sensitivity of IGROV-1 and IGROV-1/OHP cells to representative cytotoxins ${ }^{1}$

$$
\text { Mean } \pm \text { SD IC } 50(\mu \mathrm{M})^{2}
$$

IGROV-1 IGROV-1/OHP $\quad$ RI $^{3}$

Oxaliplatin

$12.7 \pm 3.1$

$928.25 \pm 78$

73

Cisplatin

$7.0 \pm 2.1$

$129.5 \pm 45.3$

18

Topotecan

$0.9 \pm 0.6$

$9.1 \pm 5.9$

10

Doxorubicin

$0.7 \pm 0.3$

$1.0 \pm 0.3$

1.4

Etoposide

$8.1 \pm 1.4$

$15.8 \pm 3.9$

2

6-mercaptopurine

$0.73 \pm 0.06$

$2.8 \pm 0.3$

3.8

${ }^{1}$ Cell sensitivity was assessed by growth-inhibition assay. Cells were exposed to drug for $1 \mathrm{~h}$ and counted $72 \mathrm{~h}$ later. For 6-mercaptopurine, drug exposure was for $72 \mathrm{~h}$ and cells were counted at the end of treatment.

${ }^{2} \mathrm{IC}_{50}$ represents the drug concentration producing $50 \%$ decrease of cell growth.

${ }^{3} \mathrm{RI}$, resistant index, is the ratio between the $\mathrm{IC}_{50}$ of resistant and sensitive cells. 
Table 2. Sensitivity of U2-OS cells over-expressing MRP1 and MRP4 to different cytotoxins ${ }^{1}$

${ }^{1}$ Cell sensitivity was assessed by growth-inhibition assay. Cells were exposed to drug for $1 \mathrm{~h}$ and counted $72 \mathrm{~h}$ later. For 6-mercaptopurine, drug exposure was for $72 \mathrm{~h}$ and cells were counted at the end of treatment.

${ }^{2} \mathrm{IC}_{50}$ represents the drug concentration producing $50 \%$ decrease of cell growth.

${ }^{3} \mathrm{RI}$, resistant index, is the ratio between the $\mathrm{IC}_{50}$ of MRP1 or MRP4 expressing cells and the $\mathrm{IC}_{50}$ of empty vector transfected cells. 
Table 3. Sensitivity of IGROV-1 cells transiently overexpressing MRP1 to different cytotoxins ${ }^{1}$

${ }^{1}$ Cell sensitivity was assessed by growth-inhibition assay. Cells were exposed to drug for $1 \mathrm{~h}$ and counted $72 \mathrm{~h}$ later. For 6-mercaptopurine, drug exposure was for $72 \mathrm{~h}$ and cells were counted at the end of treatment.

${ }^{2} \mathrm{IC}_{50}$ represents the drug concentration producing $50 \%$ decrease of cell growth.

${ }^{3} \mathrm{RI}$, resistant index, is the ratio between the $\mathrm{IC}_{50}$ of MRP1 expressing cells and cells transfected with empty vector. 
Table 4. Sensitivity of 2008 cells overexpressing MRP4 to oxaliplatin and cisplatin ${ }^{1}$

${ }^{1}$ Cell sensitivity was assessed by growth-inhibition assay. Cells were exposed to drug for $1 \mathrm{~h}$ and counted $72 \mathrm{~h}$ later.

${ }^{2} \mathrm{IC}_{50}$ represents the drug concentration producing 50\% decrease of cell growth.

${ }^{3} \mathrm{RI}$, resistant index, is the ratio between the $\mathrm{IC}_{50}$ of MRP4 expressing cells and the $\mathrm{IC}_{50}$ of empty vector transfected cells. 


\section{Figure legends}

Figure 1. Pt accumulation in IGROV-1 and IGROV-1/OHP cell lines exposed to oxaliplatin or cisplatin. A) Time-dependent accumulation of oxaliplatin in IGROV-1 and IGROV-1/OHP cells. Cells were exposed to 100 or $200 \mu \mathrm{M}$ of oxaliplatin for 30,60 and 120 min and the Pt content was determined. Symbols: - - solid line IGROV-1 $100 \mu \mathrm{M}$; squared dot line IGROV-1/OHP $100 \mu \mathrm{M}$; - - solid line IGROV-1 $200 \mu \mathrm{M}$; -o- squared dot line IGROV-1/OHP $200 \mu \mathrm{M}$ B) Concentration-dependent accumulation of oxaliplatin in IGROV-1 and IGROV-1/OHP after 1h drug exposure. Symbols: - - IGROV-1; - •- squared dot line IGROV-1/OHP C) Residual Pt content in IGROV-1 and IGROV-1/OHP cells as a function of time following exposure to $300 \mu \mathrm{M}$ oxaliplatin for $15 \mathrm{~min}$. Pt content was determined after that cells were treated with $300 \mu \mathrm{M}$ oxaliplatin for $15 \mathrm{~min}$ and incubated in drug-free medium for different times. Symbols: - - - IGROV-1; - •- squared dot line IGROV1/OHP D) Residual Pt content in IGROV-1 and IGROV-1/OHP as a function of time following exposure to $300 \mu \mathrm{M}$ cisplatin for $15 \mathrm{~min}$. Symbols: - - - IGROV-1; -•- squared dot line IGROV-1/OHP. Pt content was analyzed using flameless atomic absorption spectroscopy. The reported values are the mean $( \pm \mathrm{SD})$ of 3 independent experiments.

Figure 2. Western blot analysis of the levels of MRPs and BCRP in IGROV-1 and IGROV-1/OHP cells. Western blot analysis of MRP1 - MRP4 and BCRP was performed using total protein extracts and control loading is shown by $\beta$-tubulin. +, positive control. For MRP1: human leukemic lymphoid CEM cells, for MRP2, MRP3 and MRP4: human embryonic kidney HEK293 cells transfected with MRP2, MRP3 and MRP4 cDNA respectively, for BCRP: human breast cancer MCF-7/MR cells resistant to mitoxantrone; *, migration of deglycosylated protein. 
Figure 3. Effect of glycosylation inhibitors and endoglycosydase enzymes on the glycosylation status of MRP1 and MRP4 in IGROV-1 and IGROV-1/OHP. A) Effect of castanospermine, swansonine and tunicamycin treatment of IGROV-1 and IGROV-1/OHP cells on MRP1 and MRP4 mobility. Cells were exposed for $24 \mathrm{~h}$ to different glycosylation inhibitors and then harvested for Western blot analysis. Control loading is shown by $\beta$ tubulin. B) Effect of endoglycosydase enzymes on MRP1 and MRP4 mobility. Protein lysates were treated with PNGase F, O-glycosidase, sialidase A, $\beta$-N-acetylglucosaminidase and $\beta$ 1,4-galactosidase for $3 \mathrm{~h}$ at $37^{\circ} \mathrm{C}$ and then processed for Western blot assay. Control loading is shown by $\beta$-tubulin. *, migration of deglycosylated protein.

Figure 4. Effect of tunicamycin and knockdown of MRP4 on accumulation of cisplatin and oxaliplatin. A) Cells were treated with $0.2 \mu \mathrm{g} / \mathrm{ml}$ tunicamycin for $24 \mathrm{~h}$ before $1 \mathrm{~h}$ exposure to Pt drugs (300 $\mu \mathrm{M}$ for both oxaliplatin and cisplatin). Pt accumulation was analyzed using flameless atomic absorption spectroscopy. The reported values are the mean $( \pm$ SD) of 3 independent experiments. B) Western blot analysis of samples prepared from untransfected cells, cells transfected for $5 \mathrm{~h}$ with a MRP4 targeting siRNA or with a control siRNA and harvested $48 \mathrm{~h}$ later. Untransfected cells were exposed to vehicle alone. Control loading is shown by $\beta$-tubulin. Experiment was performed 3 times and a representative image is reported. C) Intracellular Pt accumulation in IGROV-1 and IGROV-1/OHP cells exposed for 15 min to $300 \mu \mathrm{M}$ oxaliplatin or cisplatin. Black columns, untransfected cells; white columns, cells transfected with MRP4 siRNA; grey columns, cells transfected with control siRNA. *, P<0.05 for MRP4 siRNA vs. untransfected and control siRNA (ANOVA). D) Effect of MRP4 knockdown on sensitivity of IGROV-1/OHP cells to oxaliplatin. Cells were exposed to oxaliplatin for $1 \mathrm{~h}$ and counted after $96 \mathrm{~h}$. The reported values are the mean $( \pm \mathrm{SD})$ 
of 3 independent determinations. Symbols: - $\bullet-$ IGROV-1/OHP transfected with control siRNA; -O- squared dot line IGROV1/OHP transfected with MRP4 targeting siRNA.

\section{Figure 5. Effect of knockdown of MRP1 on accumulation of cisplatin and oxaliplatin.}

A) Western blot analysis of samples prepared from untransfected cells, cells transfected for 5 h with a MRPl targeting siRNA or with a control siRNA and harvested $48 \mathrm{~h}$ later. Lane loading equivalence was document by staining for $\beta$-tubulin. Experiment was performed 3 times and a representative image is reported. B) Intracellular Pt accumulation in IGROV-1 cells exposed for $15 \mathrm{~min}$ to $300 \mu \mathrm{M}$ oxaliplatin or cisplatin. Black columns, untransfected cells; white columns, cells transfected with MRP1 siRNA; grey columns, cells transfected with control siRNA. C) Effect of MRP1 knockdown on sensitivity of IGROV-1/OHP cells to oxaliplatin. Cells were exposed to oxaliplatin for $1 \mathrm{~h}$ and counted after $96 \mathrm{~h}$. The reported values are the mean $( \pm \mathrm{SD})$ of 3 independent determinations. Symbols: - $\bullet-$ IGROV-1/OHP transfected with control siRNA; - - squared dot line IGROV1/OHP transfected with MRP4 targeting siRNA.

Figure 6. Expression of MRP1 and MRP4 in transfected IGROV-1, 2008 and U2-OS cell lines. A) Western blot assay of MRP1 in IGROV-1 cells transfected with MRP1 overexpressing vector and of MRP4 in 2008 cells transfected with MRP4 expressing vector. MRP1 and MRP4 levels were evaluated using total protein extracts. Control loading is shown by $\beta$-tubulin. B) Expression of MRP1 and MRP4 in U2-OS transfecated cells. For Western blot analysis MRP1 and MRP4 levels were evaluated using total protein extracts. Control loading is shown by tubulin. For immunofluorescence analysis cells were cultured on coverslips and than processed for immunofluorescence assay. 
Figure 7. Western blot analysis of the levels of N-acetylglucosamine-1phosphotransferase (GNPTG), mannosyl (alpha-1,6-)-glycoprotein beta-1,6-N-acetylglucosaminyltransferase (MGAT5) and of integrin $\beta 5$ in IGROV-1 and IGROV-1/OHP cells. Western blot analysis was performed using total protein extracts. Control loading is shown by $\beta$-tubulin. *, migration of deglycosylated protein. 


\section{Figure 1- Beretta and Benedetti et al}
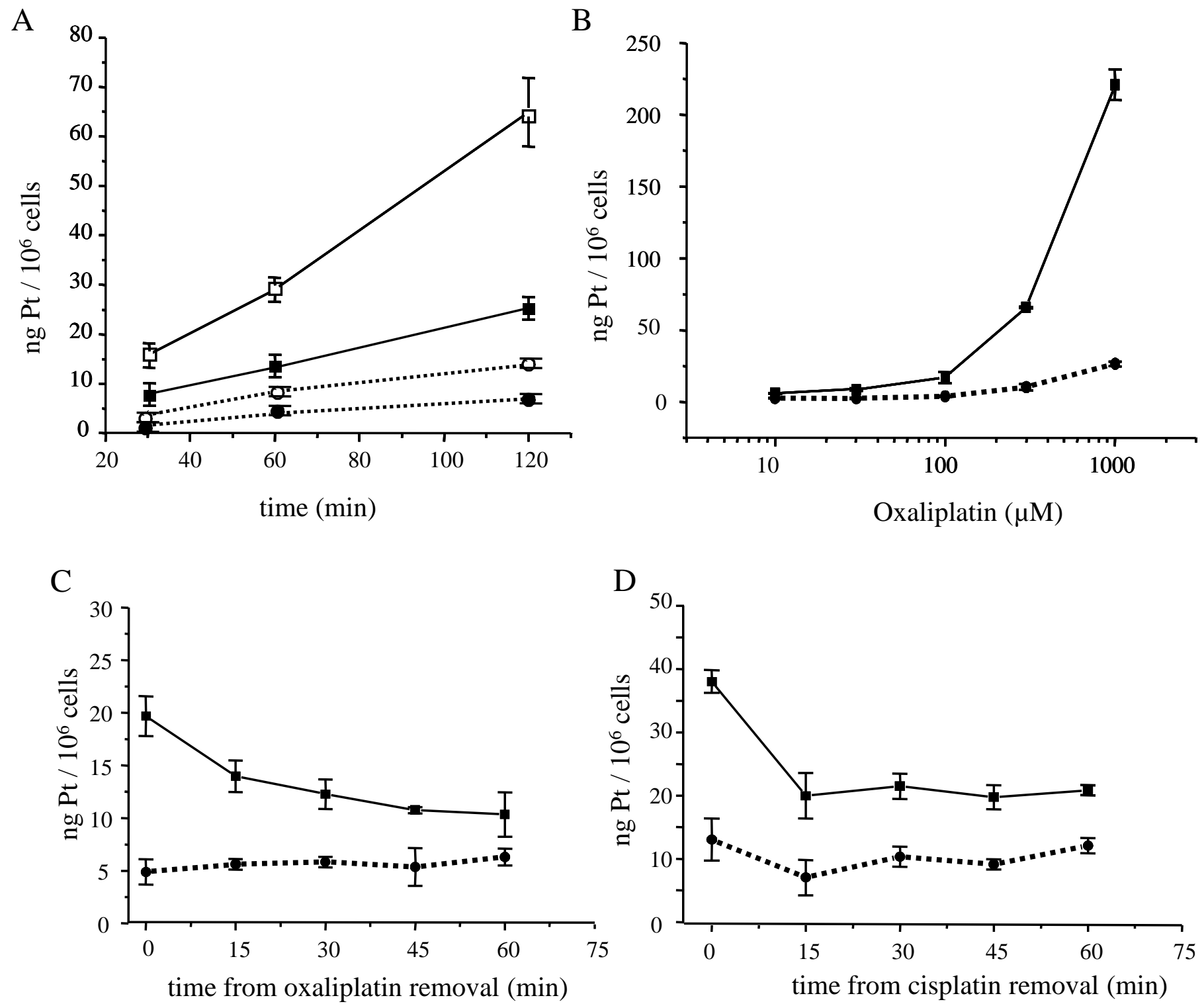


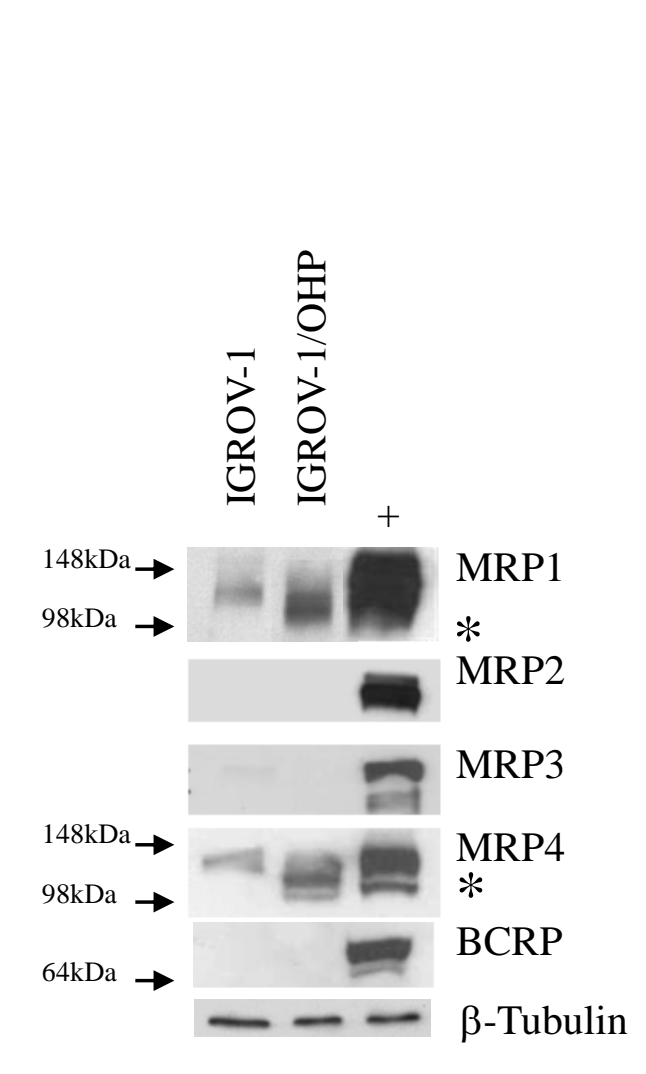

Figure 2

\section{Figure 2-Beretta and Benedetti et al}

.

.
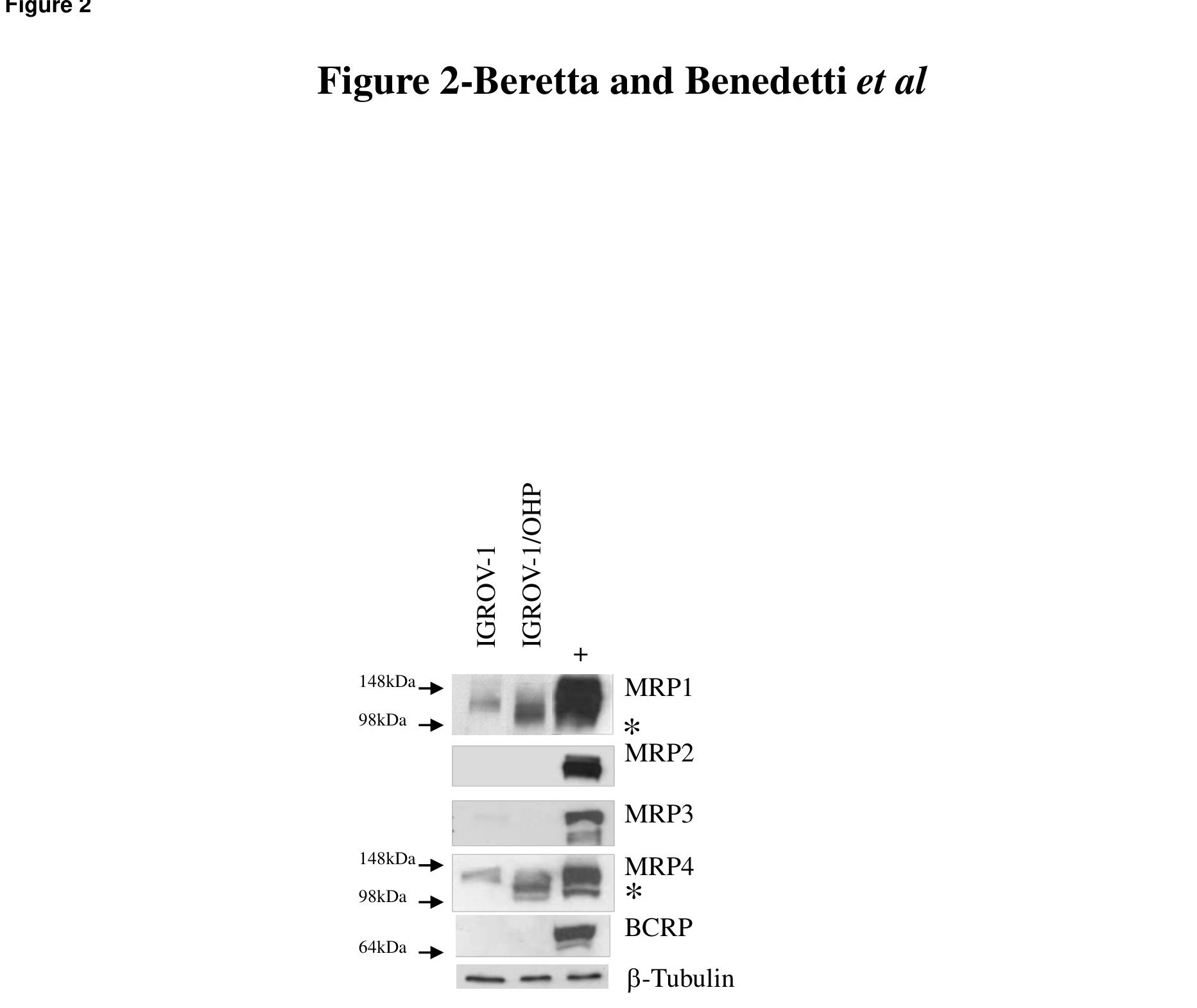

.

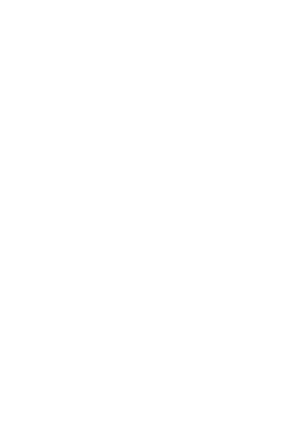




\section{Figure 3-Beretta and Benedetti et al}

A

Castanospermine $(\mu \mathrm{g} / \mathrm{ml})$ Tunicamycin $(\mu \mathrm{g} / \mathrm{ml})$

Swansonine $(\mu \mathrm{g} / \mathrm{ml})$

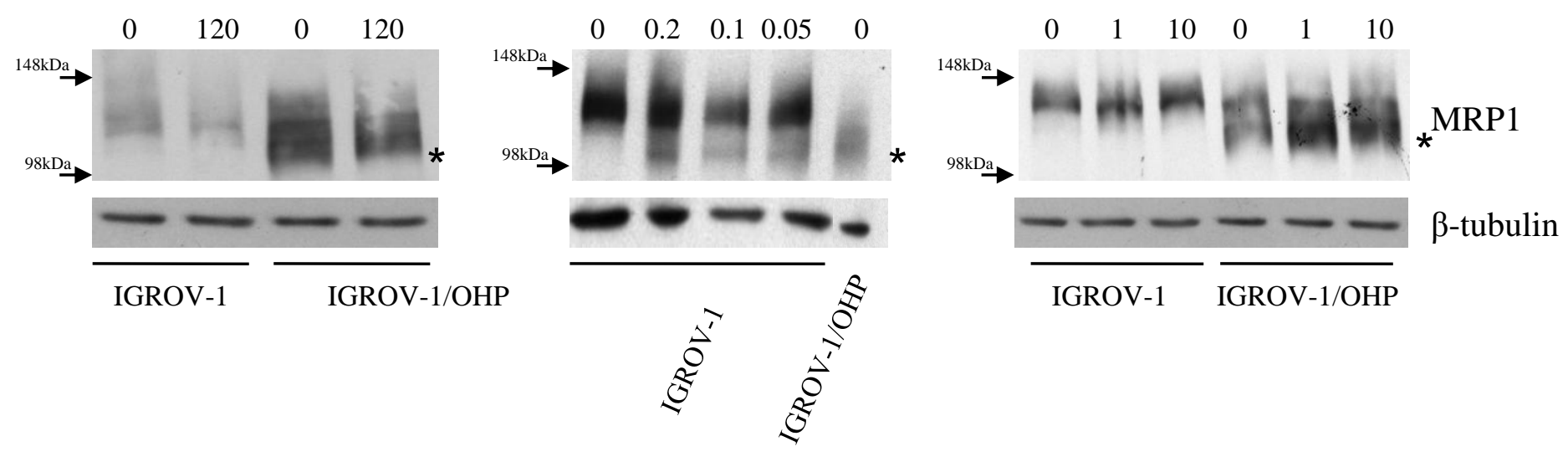

Castanospermine $(\mu \mathrm{g} / \mathrm{ml})$
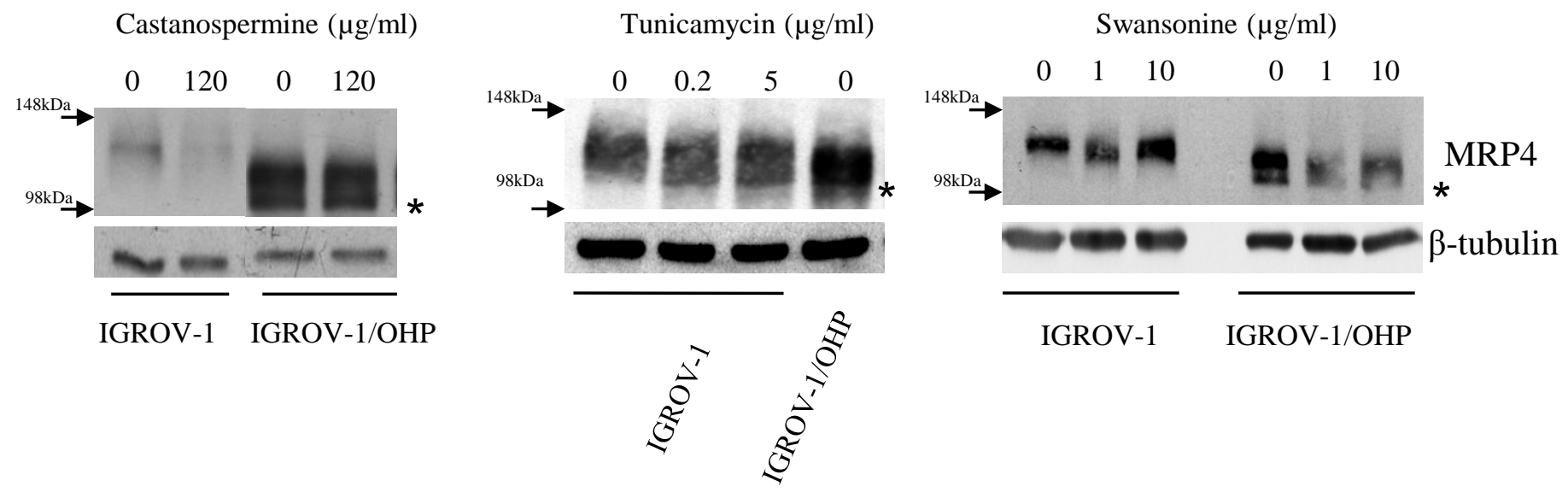

B

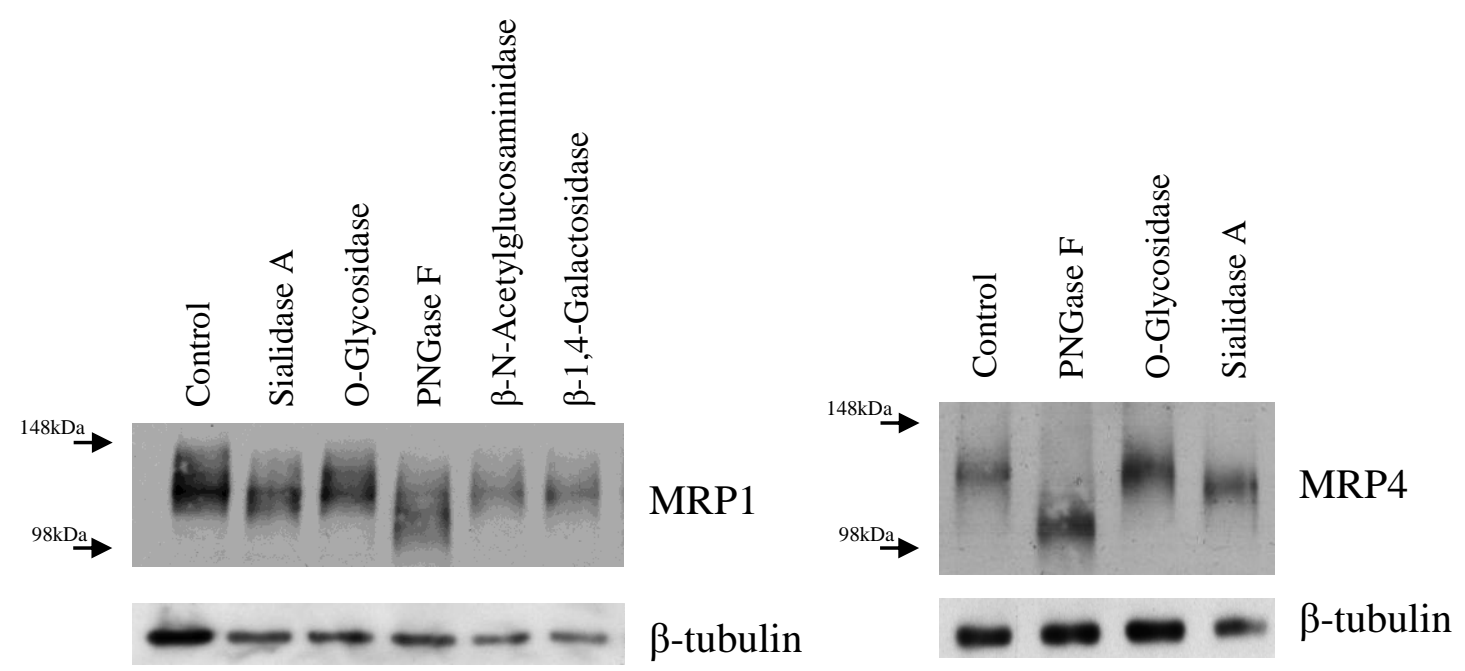




\section{Figure 5-Beretta and Benedetti et al}

A

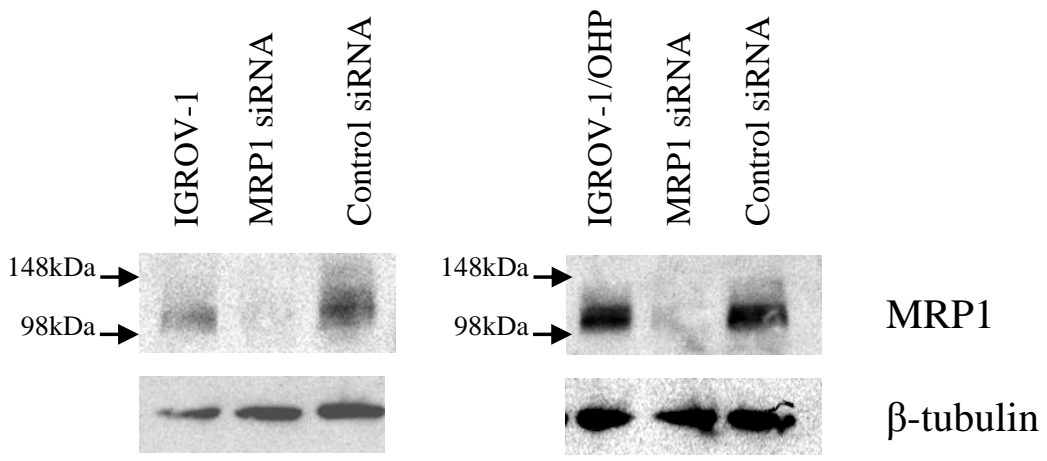

B

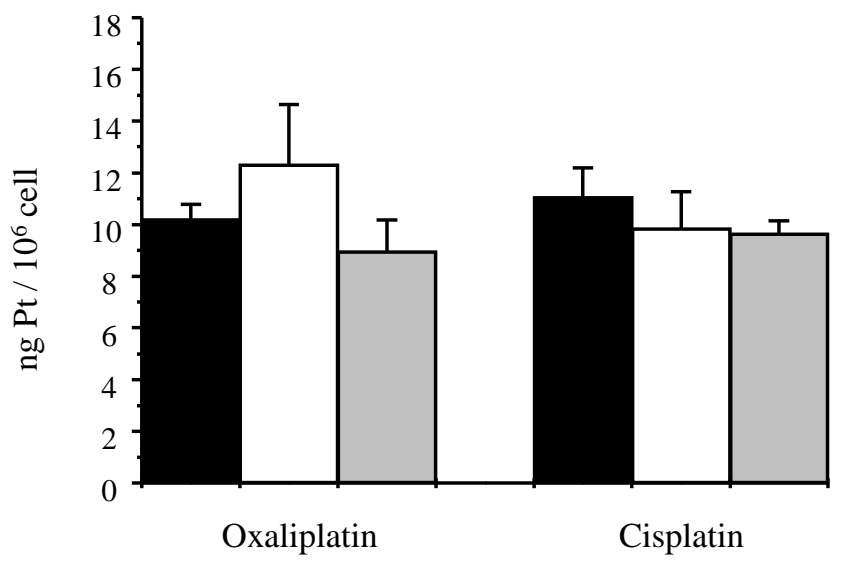

C

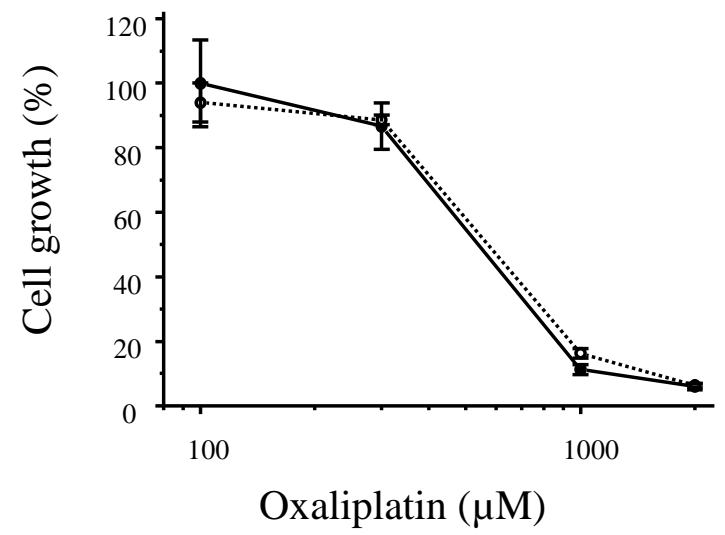


Figure 6A-Beretta and Benedetti et al

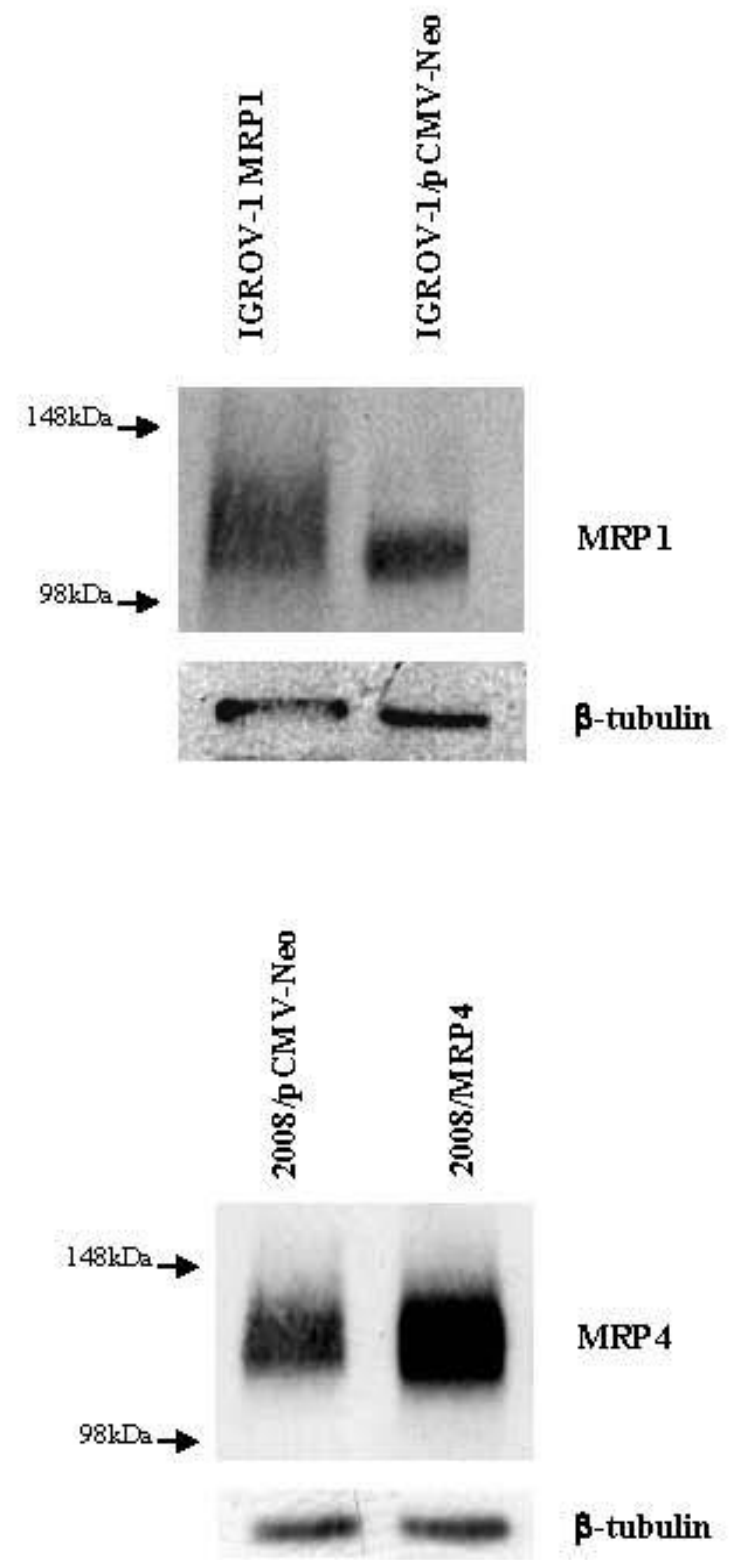

(2)

-tubalin

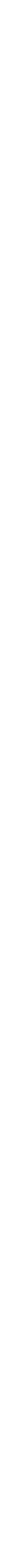


Figure 7-Beretta and Benedetti et al

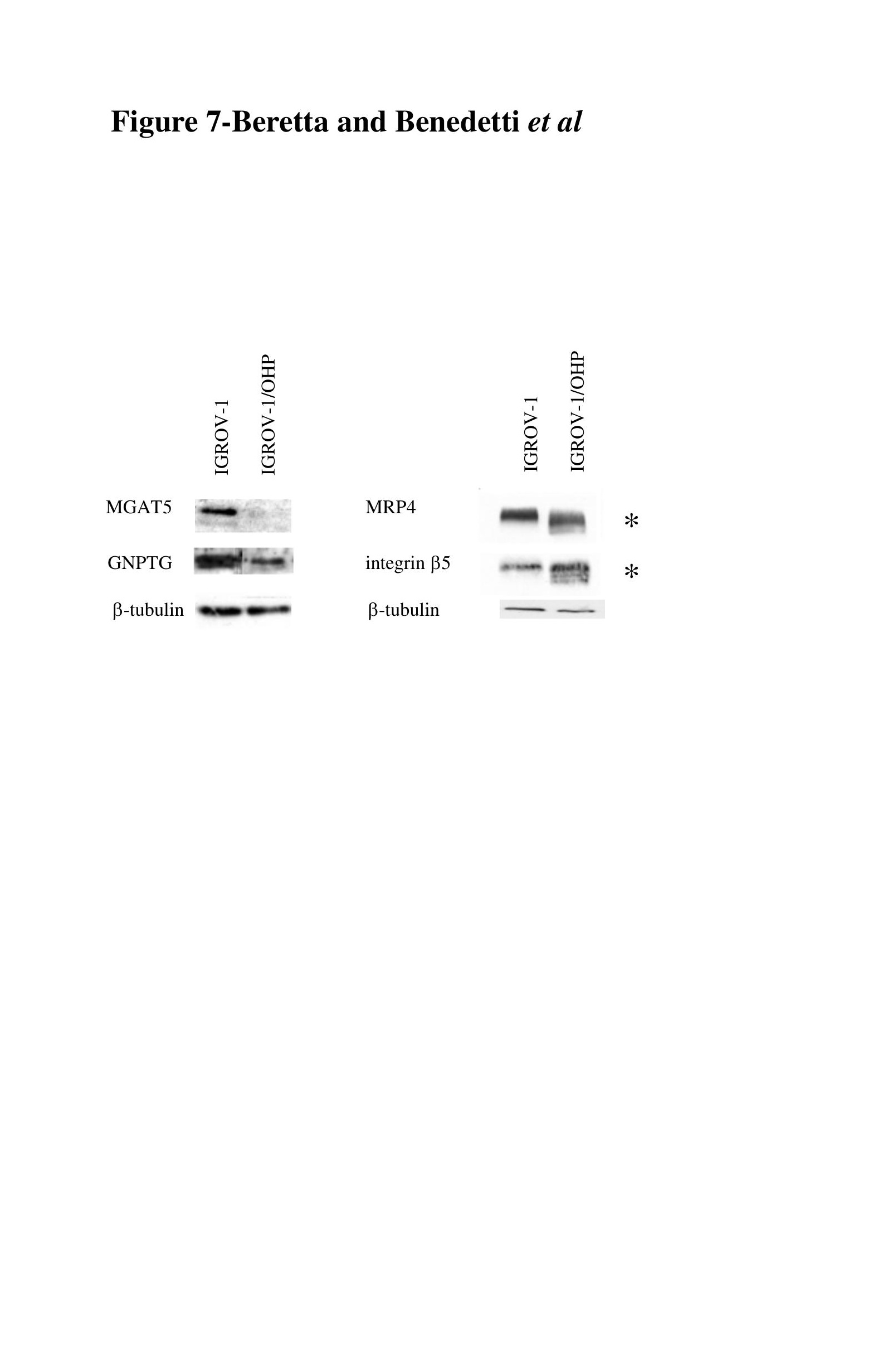

Figure 7

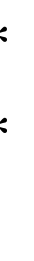




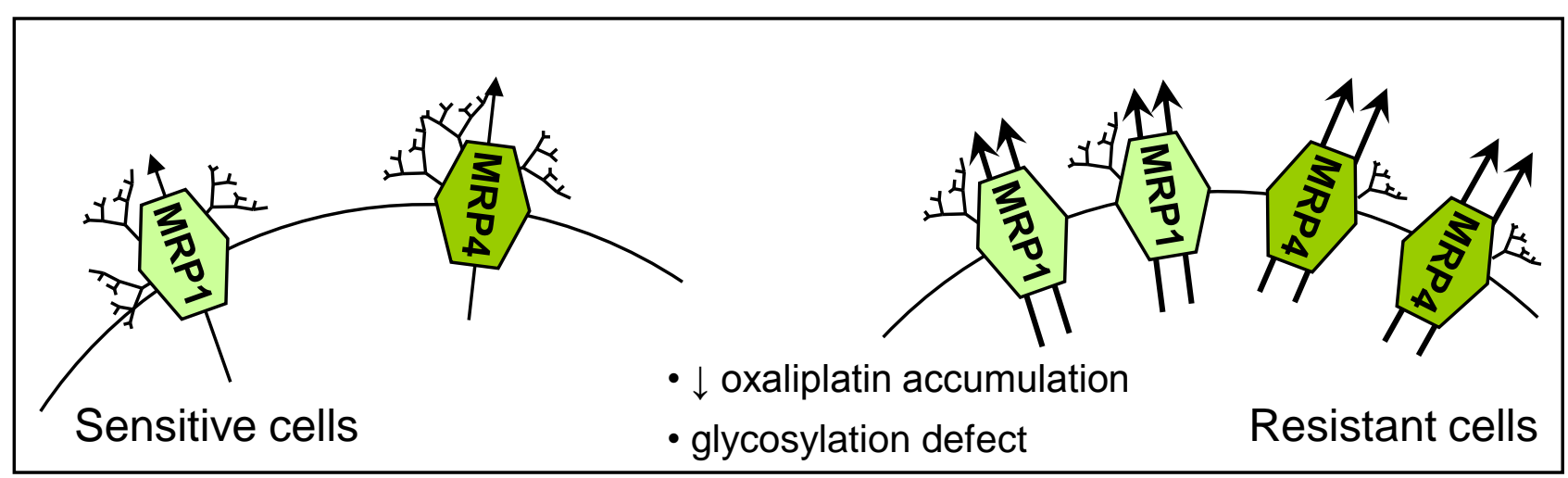

